\title{
ANNOUNCED DEMOCRACY AND DENOUNCED OPPRESSION: A CASE OF RESISTANCE IN THE TEXTILE INDUSTRY OF MINAS GERAIS, BRAZIL ${ }^{1}$
}

\author{
DEMOCRACIA ANUNCIADA E OPRESSÃO DENUNCIADA: UM CASO \\ DE RESISTÊNCIA NA INDÚSTRIA TÊXTIL DE MINAS GERAIS, BRASIL
}

\author{
Luiz Alex Silva Saraiva ${ }^{2}$ \\ Helio Arthur Reis Irigaray ${ }^{3}$
}

\begin{abstract}
The democratization of company work places has been constantly emphasized, by those inside and outside of private organizations, as evidence of the evolution of such firms. At the same time, there is growing doubt about the real possibility of the status of the worker rising to that of citizen in the company environment. In order to discuss these aspects, this article is based on a qualitative research, which utilized documents and semi-structured interviews and was conducted in an industrial textile company in Minas Gerais. The reports denounce oppression in the firm, even though it is masked by the discourse of participation and organizational emancipation. The article concludes with reflections about resistance to this situation, which exists in spite of an unfavorable environment for the workers.
\end{abstract}

KEY WORDS: Organizational democracy. Organization oppression. Hegemony. Resistance. Textile industry.

RESUMO: A democratização dos ambientes empresariais tem sido constantemente propagada tanto dentro quanto fora das organizações privadas como evidência da sua evolução. Ao mesmo tempo, crescem as dúvidas sobre as possibilidades reais de ascensão do trabalhador ao status de cidadão no âmbito da empresa. Para discutir estes aspectos, este artigo se baseia em uma pesquisa qualitativa levada a cabo em uma empresa da indústria têxtil de Minas Gerais, com base em documentos e entrevistas semi-estruturadas. Os depoimentos denunciam a opressão na empresa, ainda que mascarada sob discursos de participação e de emancipação organizacional. Conclui-se com reflexões sobre a resistência, presente mesmo em um quadro desfavorável aos trabalhadores.

PALAVRAS CHAVES: Democracia organizacional. Opressão organizacional. Hegemonia. Resistência. Indústria têxtil.

\footnotetext{
${ }^{1}$ Artigo Recebido em 05.04.2010. Revisado por pares em 26.07.2011. Recomendado em 27.08.2011 por Leomar dos Santos Editor. Publicado em 15.09.2011.

Organização Responsável pelo periódico: Universidade regional de Blumenau - FURB - www.furb.br/rn

${ }^{2}$ Universidade Federal de Minas Gerais- UFMG - saraiva@face.ufmg.br

${ }^{3}$ Universidade do Grande Rio- UGR - a.irigaray@globo.com
} 


\section{INTRODUCTION}

Since the rise of the Japanese model in the 1990's, the prevailing idea in organizations has been that subjectivity is the last field of organizational battles and a territory to be faced and conquered at any cost by firms. It is not enough to just invoke strategies to adjust the work process; it is necessary to go beyond mere occupational satisfaction of the workers and gain, with incentives, their unrestricted adhesion to the capitalist undertaking. One of the most frequently used initiatives for this, upon which rests this text, is the discourse of the firms on organizational democracy, the possibility that each worker is a citizen, an equal entity to the other members of the organization, basically given rights and duties in that collective. The use of this terminology shows, among other aspects, rhetoric about the rise of the homo economicus to the condition of citizen (PIMENTA, 1999), someone with the possibility of exercising, within the limits of the organization, more than the traditionally conceived role as followers of procedures planned at a higher level in the firm.

The company discourse attempts to broaden the perception of practices experienced by the workers to a larger universe, different and more interesting that that of the everyday professional life of the workers. On the discursive level, there are abundant images that systematically reinforce the role of the worker as a citizen, part of an organizational democracy, seen here as an effort to sustain the idea that the organization is a place equally shared by all, with the objective of reinforcing the image of harmony and equality, which are necessary for cooperation and best results.

Although the word "democracy" is historically rooted in the context of philosophy, sociology and politics, nowadays it contains a strong ideological element, not only because of the evolution implied in the term - the most advanced form of social organization - but especially due to the appeal to support for a cause, one for everyone (BOUDON; BOURRICAUD, 1993). Aside from the generosity of the concept, as a form of social existence, democracy is only viable to the degree that it creates objective conditions so that differences can be manifested and conflicts and solutions between the citizens involved can be materialized.

Citizenship implies a set of benefits that make it possible for people to participate in a political system. It suggests certain protective rights and guarantees that people enjoy. People who are part of public society should be sustained by rights and, at the same time, oriented by duties to the collective group. In order for citizenship to become an everyday practice, it is fundamentally important to not underestimate the fact that rights have to be constituted in a way that makes them easily accessible, to be also used by individuals that are less fortunate, with fewer resources, less capable. This demands a change in the pre-existing social power relationships in the political sphere (CÂMARA; CAPPELLIN, 1998).

This brings up one of the limitations of the idea of citizenship in the organizational setting. There is basically a great divergence between two groups: those who have capital, the bosses - and thus, whose order should legitimately be obeyed - and those who can simply sell their work, the workers - who need to subject themselves to the ruling scheme to exist as members of the productive community. In this respect, Cattani (1995, p. 39) argues that, "to 
reproduce, capitalism requires inequality, marginalization and exclusion," and that is why citizenship seems so fragile in the organizational setting.

In firms, the 'good new democratic attitude' is disseminated in many directions, from organizational democracy (OLIVEIRA, 1991), by way of worker-citizen (MELO; LIMA, 1995) to the concept of participation (PIMENTA, 1998), through the use of different communication mediums, which we will classify, in general, as company discourse. Although prevalent company rhetoric emphasizes the search for democratic consensus between company and workers, the daily life of the workers shows a reality in which what is observed is an attempt to force the acceptance of that unchanging reality at all costs. This implies, to a certain extent, a consent imposed by the organization.

The company discourse is changed and adapted according to the situation of evolving social conflict, with the idea of gaining cooperation from the workers, with the aim of reaching organizational objectives with as few obstacles as possible (SPINK, 1997), and is characterized, in this sense, as a strategy. Although essentially contradictory, the strategy becomes fertile ground and is actively used by the organization to try to "remove" from the workers any intentions to question the prevailing order. At the same time, this discourse tries to put in the workers' minds the notion of "unconditional partnership between capital and work," an image that brings up the metaphor of "undividable," only to reinforce paternalism and authoritarianism in Brazilian company culture (CHAUÍ, 2000). The firms hope, in this way, to involve the workers so as to reduce the disparity between their necessities and the demands of the firm, reducing the contradictions between individuals and organizations (PAGÈS et al., 1987).

What is defended in this study, however, is that participation, fundamental to the exercise of democracy, when it occurs in companies, is limited to the technical aspects of the job, concentrating on solving immediate problems. This means that the every day aspect of the practices allows for the narrow possibility of discussion, always in the operational context, not linked to the equal value that each worker has in the organization - as the company discourse puts forth - but to his/her professional experience, and, therefore, de-characterizes the exercise of democracy. In this aspect, we agree with Trejos (1997), who claims that much more than participation, what is seen is the incorporation of workers' opinions into a preexisting project, put forth by the organization, which is independent and anterior to the workers' participation in the process.

Upon being transposed to the world of organizations, the so called democracy is silenced in respect to a question put forth by Souza-Lobo (1993, p. 278): "Will social democracy be articulated as a concrete demand for democracy in a factory?" Apparently, it will not. In spite of the fact that frequently democracy and citizenship are exalted as visible signs of human freedom in the company discursive matrix, with the intention of eliminating visible signs of differences, which will also be eradicated (MELO; LIMA, 1995), the reality, however, does not seem to correspond to the company discourse. Chauí $(1989$, p. 80) argues concerning this that "Brazilian workers know the weight of repression that hangs over them every time they contest what has been established. Where is the freedom of expression, so much a part of democracy? 
The organization disconnects the everyday experience of the worker from the environment in which he/she is found; in other words, the democracy verified outside the factory doors is not seen inside them. Cooperation which is not spontaneous, but required, is something alien to genuine cooperation, according to Trejos (1997) - and decisions made by the group are limited by the operational extension of the workers' activities. This results in more than expected feelings of illegitimacy, according to Souza-Lobo (1993). Thus, even though the company line emphasizes the democratization of the present management, what is seen is restricted participation - and more or less obligatory - in relation to what the organization considers important.

The organization speaks of "public space" as if everyone in that environment had the same freedom as in public spaces, when, in fact, the workers' freedom to act is restricted, just as is the supposed notion of citizenship. It is necessary to use this discourse apparently to give the idea that the workplace is shared by all, with the objective of reinforcing the images of "harmony" and "equality." Thus, although it is a collective space, it is not organized as a public space - all components are subject to private space, presenting, in this way, domestic characteristics - which is particularly perceived in the acts of most managers, who often see themselves as having the right to interfere in the private lives of their subordinates, as land owners in former times acted with those who lived on their land (VASCONCELLOS, 1995b).

The company space, then, is ruled by its own logic, by specific regulations with the end result of good organizational performance (PAGÈS et al., 1987). In this way a paradox is created since it is demanded of a citizen in the workplace "to be content with just being a worker," but at the same time that he internalize and obey the rules and give up a series of prerogatives that he has outside the walls of the firm. Morgan (1996, p. 145), states that the worker.

As a citizen, in a democratic society is theoretically free, but his/her own opinions, upon making his/her own decisions, is to be treated as equal. As an employee all of these rights are negated. It is hoped that he/she keeps his/her mouth shut, does what he/she is told to do and submits to the absolute rule of a superior. For eight hours a day, five days a week, the worker is to forget democracy and continue working. The only democratic right that exists is the freedom to find another job and leave the firm.

To accept these conditions, which the workers frequently do, is a premise for making them (and keeping them) as members of such a community. In this space a hierarchy is established based on the differences and not the common points among the workers. The result is that the differences - and not equality - are valued as an indispensable requirement to get a place in the sun, a constant attempt to escape from the uniformity imposed by the organization in the work process.

The firms' great key to accomplishing this task is by way of economics. The work market, because of the nature of capitalism, concentrates on a constantly more restricted number of individuals benefiting from the system. Access to education, jobs, and professional opportunities are some of the examples of elements that are less and less common, and for this reason have extra importance in individual choices. In the face of limited possibilities, many 
of the workers submit themselves, accepting the system that is presented to them as being larger than them and independent of them - even though this submission is still not as widespread as the companies would like. And what is the extent to which they would like this subjection? Judging from the sophistication of the mechanisms used to simultaneously violently stimulate competition, destroy a sense of cooperation, avoid change, increase the symbolic dependence of individuals on the organization, and basically try to assimilate the individuals into the capitalist enterprise. One indication of this process is the observed emphasis on the organizations' lack of assuming any type of responsibility for the workers, a desire (never admitted) to subjugate them completely, offering them "everything" they need (according to the company): money (based on results), "democracy" and "citizenship" (associated with accepting the companies' conditions), "value" (as the organization judges adequate), etc. However, as Baudrillard (2000) alerts, exactly when all the possible advantages are offered, in reality, everything that is important is taken away.

The workers, as Souza-Lobo (1993) points out, demystify such an optimistic view of the organization since, as they try to make use, in the company, of the rights they have in the society, they perceive a kind of illegitimacy in their demand for citizenship, that is, to fight for their social and political rights inside the factory. This enters into contradiction with what is so frequently stated by the administration's discourse. Equality is not so "equal" as it is presented. In what is referred to as conditions of equality, the contradictions in the discourse are not only perceived, but also interpreted by the receivers of the organization's messages, which is a factor to be taken into consideration in the adopted form of discourse. As Prestes Motta (1992, p. 39) affirms, "The actors are not passive and, therefore, can also respond ideologically to the domination." It becomes clearer and clearer that the demand for "rights that are demanded are no longer treated on the level of equality, but on the level of differences" (CARVALHO, 2000, p. 115).

Based on the points brought up thus far, this article discusses the question of the messages of democracy put forward by contemporary organizations versus the denunciation of oppression by the workers - which translates into the daily rejection and resistance to the idea of professional and political subjugation on the part of the organization. On the one hand, on the level of managerial discourse, resources are mobilized by organizations to try to disseminate the notion of harmony and consensus, masking the relentless search for consenting to the domination; on the other hand, on the operational level, counter-discourse is developed which presents resistance to the organizational hegemony. Even without access to an official voice, the workers reinvent their daily lives, positioning themselves against what has been established by the firm's strategy.

The study is based on a textile firm in Minas Gerais (from now on called Fios), proceeding from an analysis of the official discourse of the organization and how it is processed on its different sub-levels, starting with the ways it is incorporated in the context of the organization. The material analyzed was collected in two phases. The first part - the documented research - specifically concentrates on the internal newspaper of the firm because it is the main way of "leaking" the formal discourse, the official word of the directors about the organizational daily life. The second phase was composed of analysis of semi- 
structured interviews with managers and workers from the organization done during a period of five months.

The text is organized in the following way: First, there will be a discussion of the organizational proposals for democracy and citizenship as legitimate panaceas for present social questions in the firm. Next, considerations will be presented about the seduction of the democratic discourse in the firms. Then, the text will present limitations of the discourse from a theoretical-empirical point of view, which will incorporate the counter-discourse of the workers as a reaction to the capitalist hegemony. Last, final considerations will discuss the limitations of the so-called democracy and denounce the oppression in light of practices of resistance.

\section{DEMOCRACY AND CITIZENSHIP IN THE ORGANIZATIONS: LEGITIMIZING PANACEAS?}

More than a word in vogue, the term democracy has come to represent one of the elements of countries that fight to not be marginalized in the process of historical development. As Held and McGrew (2001) affirm, various distinct waves of democratization have brought democratic processes to countries like Portugal and Spain, and at the same time similar processes have been developed in Latin America, Asia Africa, and Eastern Europe. Such "massive democratization" ended up weakening the effectiveness of democracy in those countries, as the sustenance of democracy in diverse political communities is still provisional and doubtful. According to Carvalho (2000, p. 118), the emphasis on breaking paradigms should "alert us as to the risk of running after ideas and proposals that could be only in fashion in hegemonic countries, maybe for them to remedy some confusion than to make deep changes."

More than just a political regime with parties and free elections, democracy is, above all, a kind of social existence. Democracy is an open society that always allows for the creation of new rights. A democratic state, therefore, is one which considers conflict legitimate. "It not only works toward politically diverse interests and private necessities that exist in society, but also seeks to establish them in universal rights formally recognized." (VIEIRA, 1997, p. 40). In this way, democracy, aside from being seen as a place where social funds are being well distributed, it should be seen as "a place that demands fewer funds prerequisites - so that people intervene actively in public decisions" (CÂMARA; CAPPELLIN, 1998, p. 342).

This possibility of intervention is due to exercising citizenship. The concept of citizenship, understood in its broadest meaning as "the right to have rights," has been used for diverse interpretations according to different cultural contexts. It is defined by democratic principles, consists of creating space for social struggle (social movements) and stipulates permanent institutions for political expression (parties, public organs), which means, necessarily, social and political conquest and consolidation (VIEIRA, 1997). According to Camara and Cappellin (1998, p. 351), reflections on citizenship suggest an analysis of "formulation of rules and institutional mechanisms predisposed to go beyond the declaration 
of principles. It is necessary to understand the analysis of citizenship as also including the ways of accessing rights and their concrete use by people in everyday life."

Democracy and citizenship, however, are not only concepts, but are fundamental elements to characterize the existence of social democracy, in which citizens have rights and are treated equally, starting from their differences. The democratic discourse in firms ends up, as mentioned before, presenting, on one hand, the intention to characterize the organizational environment as a legitimate social sphere, since the dichotomy worker-citizen would no longer exist.

However, there are considerable problems that are not resolved by the company organizations in the use of this discourse. Possibly the main one refers to the fact that it is necessary to make a central change in the focus of control, which would not be economically productive, but which would be based on a link as an employee, to become social, as expected in the grouping of individuals. The firms still do not answer in a clear way how they intend to give up centuries of logic based on capitalist accumulation, in which individuals are, above all, productive agents - because they are part of a process of producing goods and services for another one in which they are citizens, given collective rights and obligations

There is yet another question at least as important as the one above: what is the effective legitimacy of workers-citizens in a firm? Considering that citizenship only exists "if there is a practice of demanding rights, the appropriation of space, the struggle to make rights of citizens effective" (MANZINI-COVRE, 1999,p. 10), in most cases this is not what one sees in the productive context. There are many more instructions and adjustments to a preestablished matrix than inquiries with the aim of making the work more pleasurable (DEJOURS, 1992) and less dangerous (CASTLEMAN, 1996) in the eyes of the individuals. This is shown on a practical level, since workers, when they are not subtly stimulated to negotiate individually with the organization (PAGÈS et al., 1987), are openly threatened if they have any type of involvement with the union (GARCIA, 1999).

It would be appropriate for us to ask why the organizations have, systematically, made use of discursive matrixes that emphasize their democratic principles, even when eventually the contradictions regarding them are revealed. Saraiva et al. $(2004$, p. 67) offer a light on this upon arguing that maybe the motive for this is the fact that, "as the discourse has a clearly ideological function, which is to maintain social cohesion - in the case of the firm, of the members over which their objectives will be met - it is possible to see that the firm's intention is to hide the antagonisms in the mode of production". This systematic attempt contains within itself Darwinian logic, in that the strongest determines the rules of the game. However, if the capitalist instruments install a democracy in the organization, or if at least they say that they do, it should be real - at least in a context that builds history from the perspective of the dominators and not the dominated. For this reason it is important to hear the voice of those who are quiet not so much because of a lack of initiative, but because of suppression of the possibilities of expression.

\subsection{The seductive power of the democratic discourse}


Much of what is seen as successful in managerial terms happens when the management opportunely incorporates a discursive matrix based on convincing the workers that their interests are the same as those of the organization. Such a view emphasizes new ways of working that give more freedom to the workers, as a synonym for their professional and political emancipation. Veloso et al. (1999, p. 58) defend that, in a certain way, what is seen in the present kinds of managerial discourse is "an attempt to smooth over the paradox between the citizen and the worker, mixing the categories and making it possible for workers to give opinions about the way they perform their jobs." The flexibility - in worker organizations and in the carrying out of their jobs - is frequently pointed to as a sign of new times in which the participation of the workers will be systematically stimulated and their opinions taken into consideration. "For this reason importance is given to not only the discourse, but also the development of participative groups as a main element that will articulate a path from the informal and clandestine to the formal and controllable." (Pimenta, 1998, p. 110). Thus,

\footnotetext{
a new company discourse is developed in an attempt to implicate the workers and make them go along with the objectives of the organization, meaning not only the "end of Taylorism" as the administrative paradigm, but also the possibility of the 'arrival' of the workers to civic adulthood, to the 'rank' of citizen (...). This elasticity of the boundaries has the underlying objective of transforming the informal participation, which escapes administrative control, into open participation, de-codified and subject to company control (PIMENTA, 1998, p. 106).
}

Although control is key in the analysis of propositions on which the organizational discourse is based, naturally, communication is still relevant in this new phase of management. However, the interests of the organization go far beyond simply supplying information. According to Chauí (1989, p. 35), communication,

the information does not come down to the aspect of consuming or of persuading, but rests in the desire to seduce, which comes from the capacity of the means to convince us that we are seeing and hearing collective ideas or values. The seduction is even greater because it corresponds to a real demand for democratic space, which has public circulation of the information and the creation of an informed public opinion that can decide.

Seduction "is that which dislocates the meaning of the discourse and changes the direction of its truth" (BAUDRILLARD, 2000, p. 61). It consists of an attempt to dominate the symbolic universe of the worker, the great challenge of the present managerial strategies. The discourse put forward by the organization has premeditated characteristics, guided by the existence of a meaning, an idea of convincing the workers of the convergence of their individual interests with the organizational proposals. The legitimacy of such discourse is based on the strategy of seduction that sustains it, which makes the different organizational actors as much victims as producers of a "transfiguration of things into pure appearances" (BAUDRILLARD, 2000, p. 134). 
One of the tools most often utilized in this phase of the organization's development is the vast use of symbolic recompenses that have the function of "maintaining positive behavior and for this should be 'unforeseen' and 'intermittent' " (LIMA, 1995, p. 24). Contemporary firms, in this way, recognize the worker as a spokesperson and, for this reason, need to give him/her the impression of being respected and valued, which cannot be considered in any aspect a casual or altruistic attitude on the part of the organization, since it is involved in a larger strategic picture.

The discourse, together with various ways of seduction, influence the sphere of subjectivity of the workers in that it is presented as a representative of general happiness, a situation in which there is no longer the individual with capacity to deliberate, reflect and criticize (FREDDO, 1994). In this sense, it seeks to

\begin{abstract}
impose itself on the individual in the internal environment of the organization, seeking its legitimacy in two distinct ways: first, when the subject recognizes its ideological content, he/she starts to act according to its logic, seeking to take advantage by wearing the shirt of the firm; second, when this ideological content is interiorized, through consent, that is obtained by indoctrination. The individual does not only interiorize its logic, taking it as his/her own, but also thinks and behaves according to this same logic (FREDDO, 1994, p. 32).
\end{abstract}

This is accomplished as much by utilizing the discursive matrix itself, as by way of using various management tools. An example comes from Prestes Motta (1992) upon treating the question of development of qualifications necessary to perform different organizational functions, which is gained through training. This operates on two levels, only the first of which is directly about the technical abilities linked to performing the job. The second level, more ideological in nature, refers to the internalization by members of the firm of certain types of necessary behavior, which contributes to changing the image that the individuals have of themselves.

Alienation starts to take effect at this point of change, although it is slow and subtle but systematic - of the self-image of the workers. They start to see themselves as dependent of the organization and incapable of getting better work opportunities or even performing their activities in a more creative and dynamic way. The result of this is submission, leading to a type of "paralyzed satisfaction" with the firm and with their professional activity, since it does not exploit all the potential of the workers, but in reality represents "everything" they have.

Fios today for me is everything in my life. (worker comment)

I think that it was the best thing that happened in my life. (worker comment)

The factory is part of my life. I feel like I am part of the factory. (worker comment) 
Fios is my second home. It is my second home, here that $\mathrm{I}$, we, make our daily bread. It is here that you get your clothes, your car, your house (...) for me it is practically more of a home than home itself. (worker comment).

The notion of harmony associated with the whole idea of a management without conflict is from a seductive discourse that seeks to project this image and has its historic roots in its own local characteristics. The firm, because it produces and reproduces the values found in the place where it is implanted, brings to its daily life situations that are similar to those that were developed in the society to which they belong, which includes the (apparent) limitations of the environment to make possible the concept of other ways of private organizational life, different from those in effect.

\subsection{Limitations of the democratic discourse in firms}

In a context of constant transformations, in the organizational environment one sees the development of a series of instruments aimed at attending the demands originating in that environment, among which the firm's discourse stands out as one of the most contemporary faces of management. The discourse is seen as a sophisticated way of dominating inside an organization, as well as a way of disseminating capitalist values on the microeconomic level.

It is common to see the use of the present situation, unfavorable in many aspects for the workers, as an instrument of differentiation, although the organization struggles to hide such an intention by arguing that the workers are citizens who exercise the rights and duties of the firm:

Here you have total freedom; you decide what is good. You also have responsibilities. If you are good, you have responsibility that is good, and if something bad happens, you are also responsible. (worker comment).

The workers, however, as Souza-Lobo (1993) point out, demystify such an optimistic vision of the organization, since as they try to use in the company the same rights they have in the society, they see a kind of illegitimacy in the claim for citizenry, which is to fight for their social and political rights inside the factory. This enters into contradiction with what is so frequently put out by the administration's discourse. Equality is not so "equal" as it seems.

As to conditions of equality, the contradictions in the discourse are not only noted, but also interpreted by those addressed by the organization, which is a factor to be taken into consideration in the construction of the discursive matrix to be adopted. It becomes increasingly clear that there is a demand for the "rights that call for treatment no longer on the basis of equality, but on the basis of differences" (CARVALHO, 2000, p. 115). This is shown, in particular, in the distinction that exists between who is inside and who is outside, or, to be clearer, between the "chosen" (the formal employees) and the "excluded" (the precarious or unemployed). 
Everyone is scared; everyone is afraid to leave. Nobody wants to leave [the firm, lose a job] (worker comment)

As a rule, elements emphasized in Brazilian organizations are antagonistic to practical every day life, not uncommonly being a mixture of authoritarianism and oppression in the organizational environment, which would go against the emphasis given to participation and democracy. According to studies available at the moment, managerial practices remain linked to the traditional sphere. Souza-Lobo (1993, p. 274) assert that "if the prescription is really for competition and productivity, it is true that its application continues to be restricted and selective." Their point of view is based on the fact that this new way of facing management, as much as it has been dressed to modern clothes, does not question, in fact, the Ford organization of production. Britto (1999), in this respect, maintains that the modernization of organizations still is done in an unequal way, depending on the sector or branch of production, and even inside the branch, presents itself as still being partial.

On many occasions, the discourse about participation has been presented "to squelch the conquests of the worker movement in terms of mobilization and organization in the work place, or to respond and offer opposition to the effects of these conquests" (SOUZA-LOBO, 1993, p. 275). In this way, the canals open for participation are limited to the mark set by the management (TREJOS, 1997), which shows that normally preferred appeal to a discourse structured around participation and responsibility, without, however, forgetting authoritarian practices" (SOUZA-LOBO, 1993).

To try to explain the authoritarian picture that characterizes the local environment, Souza-Lobo (1993, p. 276) point out two factors. Initially, the

\footnotetext{
managerial practices based on the authoritarian and/or paternalistic tradition, with very hierarchical relations between the managers and the workers, which is only accentuated by the distance between the background and education between the two groups. In the second place, Brazilian political culture has a strong, authoritarian tradition that deeply marks the relations between the groups and individuals.
}

Sales (1994, p. 26) shares this point of view, defending that the question of historical social inequality "has been the presentation card of Brazil to the world". In the Brazilian reality sub-developed areas live side by side with other areas, as is the case in certain regions of the northeast and the suburbs of great urban centers in the country. Paulista Avenue (a main street in São Paulo) is an active stage, although on the periphery, of globalization of capital, which rejects its quota of participation in the promotion of inequality. Such inequality mainly economic - anchored in a history of concentration of income, restricts the internal market with multiple effects on the makeup of the national economy.

Concerning the local situation, Saes (1996, p. 9) affirms that "Brazilian industrialization is developed on the basis of the incorporation of technological conquests made by industry in the main capitalist countries," at a fast rate, whether taking into consideration the time that the process happened in relation to developed countries, or considering the stage of internal development of productive forces. Vasconcellos (1995) 
argues that the Brazilian business class was not forged in a struggle with the workers, in which it would have had to negotiate and develop managerial techniques to persuade and/or seduce. On the contrary, its answers were always through authoritarianism, which explains the delay in local managerial reformulations.

The historical tradition of subordination to the more developed colonizers contributed to the managers accepting naturally the idea that it is necessary to copy what is already successful in other business realities, not considering the local abilities and characteristics. Innovations are imposed because the workers are workers (and apparently in constant state of temporality), subordinate to the orders of the bosses, who have the power to control them and discipline them, reproducing in their organizations the cultural stereotypes of rich and poor, farmers and farm workers, slave-owners and slaves (VASCONCELLOS, 1995a). This reality ends up affirming the words of Telles (1993, p. 17), which point out that in Brazil, "it is this that allows us to say that insecurity is the defining element of the way of life."

For this reason, a large number of individuals tend to see their psychological and social lives as impossible without being tied to the organizations, which always happens according to the role and the reasonably formalized and differentiated status that they have been "attributed". This "attribution" must be done by other individuals "not peers," but "superiors" on the hierarchy, which undermines the democracy preached on the level of the discourse. This is not about duties and rights, but the professional obligations and official rights.

\section{THE DENOUNCE OF OPPRESSION AT WORKERS' COUNTER-DISCOURSE}

In spite of the democratic appeal as a superior kind of freedom and of its presentation in the organizational context, the workers denounce that if it is democracy they experience in the organization, it is of a very peculiar type. What can be disagreed with, what can be participated in, and even to what point the participation can go are aspects out of the hands of the worker-citizens: they are questions defined by the firm and according to its strategic conception. However, it is not convenient to widely reveal this fact to those interested. Thus, the firm develops sophisticated discourse matrixes, which are designed to convince the workers of the absolute necessity of their participation and to stress the fact that without their presence there is no meaning to the organizational practices. One of the most interesting concepts is the question of participation, given as a money tradeoff with the workers. The level of democratic participation today is compared to the 'not so democratic' participation yesterday (never authoritarian, by the way). The following comment illustrates this aspect.

[Before] your opinions wasn't worth anything. You were the worker and that's all. Today no; on the part of the bosses and with this management that is here, what you say they listen to. When you work like me, eight years on a machine, I have to know the machine. The worker policy here is: you have your own opinion, you can question, you have the freedom to go to the manager's room and talk, give your opinion. (worker comment) 
It is obvious from this comment that the worker has absorbed the firm's perspective regarding the evolution of worker relations. "Yesterday" there was only an employee relationship. Today, there is an employee relationship in which there is also an interest -- but an operational one, in the possibilities of improving the productivity of the worker through his/her participation. This is a typical process of conversion of tactical knowledge into explicit knowledge, available to the organization, and to which it normally has access 'opening the democratic canals,' 'letting the workers play at being citizens' in organizational domains. The possibility that workers give their opinions is not linked to an objective importance of participation. The possibilities of expression are not associated with a sense of criticism, intellectual capacity, or the role of citizenship, but above all, with job experience. This is the sense of so called participation in the firms.

With the advance of the perspective of 'citizen' firms (RAMPINELLI; GUIMARÃES, 2006), there is an enormous value given to organizations acting to promote citizenship, inside as well as outside their environment. For this reason, 'citizen participation' is presented to the workers as an option. After all, it is necessary that the market maintain the fetish for democratic equality even when everyone involved knows that things are really not like that. The workers without a 'participant profile,' who have opted to be strictly professional as in the old mode, with no compromise beyond the relationship of buying and selling work hours, can be punished for not behaving as is desired. Participation becomes, in itself, a criterion of inclusion or exclusion, as the following comment shows:

[To stay in the firm] you have to participate, participate all you can in the firm, you have to participate. [If] you don't participate in anything, you will be a nobody, and it is better to be recognized than not be recognized (worker comment)

\section{CONCLUSIONS}

The absence of well-defined limits between the public and private domains, characteristically Brazilian is also found in organizational environments. The lack of clarity in respect to where one domain ends and the other begins makes it so that in the sphere of the firm there is a logic for which workers are used in the way they find most convenient, under constant threat of punishment, that goes from small warnings to even being dismissed from the firm. Although he did not have a low opinion of the private sector, Arendt (1999, p. 68) considered that for an individual to live an entirely private life meant, above all, that he/she would be destitute of the things essential to a truly human life.

to be deprived of reality that comes from being seen and heard by others, deprived of an 'objective' relationship with them because of being connected and being separated from them through a common world of things, and deprived of the possibility of fulfilling something more permanent than one's own life. 
Overall, a distinction between the public and private sectors, "seen from the point of view of privacy and not of the political body, is the same as the difference between what should be shown and what should be hidden" (ARENDT, 1999 p. 82). Thus, "the loss of public space means, now with an explicitly political meaning, the loss of space recognized of action and opinion, which is to say, the loss of freedom that demands, to be effective, a politically organized space" (TELLES, 1990, p. 29). Continuing the argument, this author asserts that

the loss of a shared reference of meaning, where the action and the word of each one can be seen as something that matters for conducting human business, that it is accompanied by impotency. This translates specifically as the loss of space in which the action and the word can be expressed as power. This impotence goes with the lack of capacity to develop a common history (TELLES, 1990, p. 37).

It could be particularly questioned here if it is, in fact, an inability to develop a common history. Apparently, this is not only a problem of developing, but of legitimacy, since the common history that could be developed, in this case is underground, illegitimate, exactly because it is not official, not coming from who decides in the private sphere. Telles (1990, p. 36) continues his explanation, defending that

\footnotetext{
the dissolution of public space means the impossibility of a tradition being created or refined. And, if this is serious, it is because without a tradition, thinking is without limits to consider an event that (...) without this containment given by words and by memory, is fragmented and vaporized throughout time, homogeneous, without actual human meaning...
}

This argument translates part of what happens in the firm in what refers to processes of communication. As there is not a public tradition, with spokesperson, as already discussed, the managers "choose" the history that is told to the workers, once they have the formal means of perpetuating a "created tradition" of (and for) the organization.

The firm, although it is a collective space, is not run as a public space, but it subjects to norms of a public space all of its components, showing, in this way, domestic characteristics. This is particularly perceived in the action of a large number of the managers, who frequently think they have the right to intervene in the private lives of their subordinates, as in the past the landowners did with their farm workers (VASCONCELLOS, 1995b). The organization uses the discourse of public space, as if all of those in the environment of the firm had the same freedom as those in public spaces, when, in fact, freedom of action is restricted as is the supposed notion of citizenry. This discourse needs to be used apparently to give the idea that there is an environment shared by all, with the purpose of reinforcing the images of "harmony" and "equality":

The work is done by the participation of groups of workers. We have implanted a series of things, as statistical control of production. The worker himself/herself has knowledge as the operator the machines but also of the levels he/she has to reach, the objectives to be reached. 
$\mathrm{He} / \mathrm{she}$ is in control, is the one who measures. At the time he/she changes groups, he/she communicated to the others what he/she is receiving. Therefore, we have instigated him/her to really participate in the problems and their solutions. There has to be a directed technology; you can't let things just go (manager's comment).

The values relative to the unit that the organization should possess are systematically emphasized, not only by the existing company discourse, but also especially in the social practices given, which create the illusion of "rising citizen" in the context of the organization. This illusion - it is valuable to note - is not of the workers. They know perfectly well what their firm's strategy is about, and they defend themselves as they can, discarding what is not in their individual interests. In other words, when it is useful for them to be cooperative, they are. This is not always on a conscious level, but the intention is present. The threatening economic context does not leave the people without defenses to the system that is presented to them as much bigger than them and independent of them.

For now, the rise, in reality, of the worker to the status of citizen, in the context of a democratic organization, widely open to discussion and redefinition, remains an ideal to be sought, which, evidently, stimulates the search for a solution that makes the organizational environment more humanized - in practice, and not only on the level of discourse. Discrepancies that exist in the firms - notably in what applied to dissemination of the democratic discourse and the denunciation of oppressive practices - which instead of presenting a dark picture for the business class, have shown how an element of secondary importance in the present situation of power between employers and workers, at this moment favorable to the firms' initiatives in detriment to the effort of the workers. In general, this is because by definition, the use of and the modernization of managerial practices are of primary importance to the business class - and not of the workers.

This does not mean, however, that this game is won. Much to the contrary, capitalism is cyclical, and just as there were moments in which the business class found themselves without a way out, because of the power of the union movement, and knew how to reinvent themselves to face the challenge, this is a moment in which the workers feel pushed back and pressured on all sides, but they have not been absolutely defeated. To assume the inexorable victory of capitalism is to condemn men to a secondary role in a history created by them themselves. A singular discourse which converts everything and everyone into disposable objects attempts to convince all that another future in not possible. To resist this is the task of all.

\section{REFERENCES}

ARENDT, H. A condição humana. 9. ed. Rio de Janeiro: Forense universitária, 1999.

BAUDRILLARD, J. Da sedução. 3. ed. Campinas: Papirus, 2000.

BOUDON, R.; BOURRICAUD, F. Dicionário crítico de sociologia. São Paulo: Ática, 1993. 
BRITTO, J. Modernização produtiva e evolução do emprego e qualificação profissional na indústria têxtil. In: ENCONTRO NACIONAL DE ESTUDOS DO TRABALHO, 6, Belo Horizonte. Anais... Belo Horizonte, ABET, 1999. v. 2.

CÂMARA, C.; CAPPELLIN, P. Gênero, trabalho e cidadania nos anos 90. Contribuições para Atualizar o Referencial Teórico. In: ABRAMO, L.; ABREU, A. R. P. (Org.). Gênero e trabalho na sociologia Latino-Americana. São Paulo; Rio de Janeiro: ALAST, 1998.

CARVAlHO, J. M. Cidadania na encruzilhada. In: BIGNOTTO, N. (Org.). Pensar a república. Belo Horizonte: UFMG, 2000.

CASTlEMAN, B. I. A migração dos riscos industriais. Caderno CRH, Salvador, n. 24/25, p. 41-67, jan./dez. 1996.

CATTANI, A. D. Processo de trabalho e novas tecnologias: orientação para pesquisas e catálogo de obras. Porto Alegre: UFRGS, 1995.

CHAUÍ, M. Brasil: mito fundador e sociedade autoritária. São Paulo: Fundação Perseu Abramo, 2000.

CHAUÍ, M. Conformismo e resistência. 4. ed. São Paulo: Brasiliense, 1989.

DEJOURS, C. A loucura do trabalho. 5. ed. São Paulo: Cortez/Oboré, 1992.

DINIZ, E.; BOSCHI, R. R. Lideranças empresariais e problemas de estratégia liberal no brasil. Revista Brasileira de Ciências Sociais, São Paulo, n. 23, p. 101-120, out. 1993.

DRACHE, D. Globalização: o grande medo. Revista de Administração, São Paulo, v. 34, n. 1, p. 9-28, jan./mar. 1999.

FREDDO, A. C. O discurso da alienação nas organizações. Revista de Administração Pública, Rio de Janeiro, v. 28, n. 1, p. 24-33, jan./mar. 1994.

GARCIA, F.C. A crise asiática e os desafios da concertazione social no Brasil. In: PIMENTA. S. M. (Org.). Recursos humanos: uma dimensão estratégica. Belo Horizonte: UFMG/FACE/CEPEAD, 1999.

HELD, D.; McGREW, A. Prós e contras da globalização. Rio de Janeiro: Jorge Zahar, 2001 .

IANNI, O. A idéia de brasil moderno. 2. ed. São Paulo: Brasiliense, 1994.

LEITE, M. P. Reestruturação produtiva, novas tecnologias e novas formas de gestão da mãode-obra. In: OLIVEIRA, C. A. B., MATTOSO, J. E. L., SIQUEIRA NETO, J. F., POCHMANN, M.; OLIVEIRA, M. A. (Org.). O mundo do trabalho: crise e mudança no final do século. São Paulo: Página Aberta, 1994.

LIMA, M. E. A. Os equívocos da excelência: as novas formas de sedução da empresa. Petrópolis: Vozes, 1995.

MANZINI-COVRE, M. L. O que é cidadania. São Paulo: Brasiliense, 1999. 
MELO, M. C. O. L.; LIMA, M. E. A. A nova ordem contratual na empresa: cidadania e relações de trabalho. In: NEDER, R. T. (Org.). Olhares sobre a gestão a cidadania no Brasil. São Paulo: Paulicea, 1995.

MORGAN, G. Imagens da organização. São Paulo: Atlas, 1996.

OLIVEIRA, G. Democratização das relações de trabalho na empresa. Revista de Administração de Empresas, São Paulo, v. 31, n. 4, p. 91-95, out./dez. 1991.

OLIVEIRA, M. A. Notas sobre a crise do novo sindicalismo brasileiro. São Paulo em Perspectiva, São Paulo, v. 12, n. 1, p. 24-29, 1998.

PAGÈS, M., BONETTI, M.; GAULEJAC, V.; DESCENDRE, D. O poder das organizações. São Paulo: Atlas, 1987.

PIMENTA, S. M. A estratégia da gestão na nova ordem das empresas. In: Recursos humanos: uma dimensão estratégica. Belo Horizonte: UFMG/FACE/CEPEAD, 1999.

PIMENTA, S. M. Participação e qualificação: uma nova sincronia de gestão. Trabalho e Educação, Belo Horizonte, n. 4, p. 99-114, ago./dez. 1998.

PRESTES MOTTA, F. C. As empresas e a transmissão de ideologia. Revista de Administração de Empresas, São Paulo, v. 32, n. 5, p. 38-47, nov./dez. 1992.

RAMPINELLI, G. B.; GUIMARÃES, V. N. Responsabilidade social corporativa: desvelando intencionalidades não reveladas. In: PIMENTA, S. M.; SARAIVA, L. A. S.; CORRÊA, M. L. (Org.). Terceiro setor: dilemas e polêmicas. São Paulo: Saraiva, 2006.

SAES, D. Democracia e capitalismo no Brasil: balanço e perspectivas. Revista de sociologia e política, Curitiba, n. 6-7, p. 1-21, jun./nov. 1996.

SALES, T. Raízes da desigualdade social na cultura política brasileira. Revista brasileira de ciências sociais, São Paulo, n. 25, p. 26-37, jun. 1994.

SARAIVA, L. A. S.; PIMENTA, S. M.; CORRÊA, M. L. Dimensões dos discursos em uma empresa têxtil mineira. Revista de Administração Contemporânea, Curitiba, v. 8, n. 4, p. 57-79, out./dez. 2004.

SOUZA-LOBO, E. Modelo japonês e práticas brasileiras. In: HIRATA, H. S. (Org.). Sobre o modelo japonês: automatização, novas formas de organização e de relações de trabalho. São Paulo: EDUSP, 1993.

SPINK, P. K. Discurso e ideologia gerencial: reflexões a partir da experiência brasileira. In: PRESTES MOTTA, F. C.; CALDAS, M. P. (Org.). Cultura organizacional e cultura brasileira. São Paulo: Atlas, 1997.

TELLES, V. S. Espaço público e espaço privado na constituição do social: notas sobre o pensamento de Hannah Arendt. Tempo social, São Paulo, v. 2, n. 1, p. 23-48, 1.sem. 1990.

TELlES, V. S. Pobreza e cidadania: dilemas do Brasil contemporâneo. Caderno CRH, Salvador, v. 19, p. 8-21, jul./dez. 1993. 
TREJOS, M. E. Calidad total, control y trabajo. Revista Latino-Americana de Estudos do Trabalho, São Paulo, n. 6, p. 167-178, 1997.

VASCONCELLOS, J. G. M. O coronelismo nas organizações: a gênese da gerência autoritária brasileira. In: DAVEL, E. P. B.; VASCONCELLOS, J. G. M. (Org.). "Recursos" humanos e subjetividade. 2. ed. Petrópolis: Vozes, 1995a.

VASCONCELLOS, J. G. M. A invenção do coronel. Vitória: EDUFES/FCAA, 1995b.

VElOSO, H. M., ROCHA, C. H. M., LANARI, C. S.; ARRUDA, A. G. S. As transformações do mundo do trabalho. In: PIMENTA, S. M. (Org.). Recursos humanos: uma dimensão estratégica. Belo Horizonte: UFMG/FACE/CEPEAD, 1999.

VIEIRA, L. Cidadania e globalização. Rio de Janeiro: Record, 1997. 